\section{EN EL ORIGEN DE LA NOVELA CORTA DEL SIGLO DE ORO: LOS NOVELLIERI EN ESPAÑA}

\section{David González Ramírez}

Universidad de Málaga

Departamento de Filología Española I y Filología Románica Facultad de Filosofía y Letras, Campus de Teatinos Universidad de Málaga. C.P. 29071, Málaga

(davidgr@uma.es)

\begin{abstract}
This study presents an overview of the reception and impact in Spain of the novellieri who were translated into Castilian. The issues that have been analyzed are those which are the most interesting in bibliographical problems and questions about translations of the works of Straparola, Guicciardini, Bandello and Giraldi Cinzio, all of them appeared between 1580 and 1590. Finally, it provides a number of suggestions which we will keep in mind in order to reconstruct with sufficient guarantees the first chapter in the history of the novel in Spain, whose main axis is the dissemination of novellieri in Spain.
\end{abstract}

KEY WORDS: Straparola; Guicciardini; Bandello; Giraldi Cinzio; Italy; Spain; Golden Age.

\section{ON THE ORIGIN OF THE SHORT STORY OF THE GOLDEN AGE; THE NOVELLIERI IN SPAIN}

RESUMEN: Este estudio presenta un panorama general sobre la recepción y el impacto en España de los novellieri que fueron traducidos al castellano. Se han abordado aquellos aspectos que reúnen más interés sobre los problemas bibliográficos y las cuestiones derivadas de las traducciones de las obras de Straparola, Guicciardini, Bandello y Giraldi Cinzio, aparecidas todas entre 1580 y 1590. Finalmente, se aporta una serie de sugerencias con las que habrá que contar para tratar de reconstruir con suficientes garantias ese capitulo liminar de la historia de la novela en España que tiene como epicentro la difusión de los novellieri en España.

PALABRAS CLAVE: Straparola; Guicciardini; Bandello; Giraldi Cinzio; Italia; España; Siglo de Oro.

Trató esta dama de que [...] la entretuviesen, ya con música, ya con danzas y ya con novelar, ejercicio muy usado en Italia; díganlo los Bandelos, Sansovinos y Bocacios, que tantos tomos han impreso dellas, y ahora en España los han excedido con grandes ventajas.

Castillo Solórzano, La quinta de Laura, 1649

\section{LA CRÍTICA Y LOS TEXTOS: UNA TAREA PENDIENTE ${ }^{1}$}

Desde principios del siglo XX una parte de la crítica comprometida con el estudio de la narrativa del seiscientos viene reclamando, aunque no con la suficiente entidad de razones constatadas, un estudio de conjunto que llegase a revelar la verdadera influencia que ejercieron los novelistas italianos posboccaccianos en el origen y la formación de la novela corta española. El desideratum no ha pasado nunca de bosquejar con trazos discontinuos y desiguales la aproximación a un escenario que, con los pocos apuntes puestos en circulación, no podríamos más que delinear con muy frágiles fundamentos. En su conocido Discurso de ingreso en la Real Academia Española, Agustín G. de Amezúa (1951 [1929], I: 250) presentó lo que él mismo había concebido como un ensayo preparatorio para la Historia de la novela cortesana en España que estaba planeando. En las páginas de ese estudio, al reparar en la presencia compartida de temas y tramas entre los novellieri y los continuadores de Cervantes, aseguró que en ocasiones los "contactos fueron más vivos en unos ingenios que en otros", llegando a apuntar que autores como "Ágreda, Lugo, Castillo Solórzano, Castro, Piña, Camerino, Aguirre llegan a veces al plagio, ora de argumentos, ora de frases enteras". 
Sin embargo, Amezúa, por no rebasar los límites de su estudio, no llegó a dar ejemplos de estos débitos; estas escuetas líneas, a su modo, hay que entenderlas como una clara objeción a lo que algunos años antes Menéndez Pelayo (1943 [1910]: 28) había dejado anotado en el tercer tomo de la serie que consignó como Orígenes de la novela, cuando llegó a asegurar que en la tradición de la novelística española del XVII "hubo también, aunque en menor número de lo que pudiera creerse, imitaciones de novelas sueltas, escogiendo por de contado las más honestas y ejemplares". Continuaba explicando Menéndez Pelayo que intentaria "completar" la "tarea ya brillantemente emprendida por miss Bourland" en 1905 cuando tratase "de cada uno de los autores en la presente historia de la novela"; pero como la empresa en la que se embarcó quedó finalmente truncada (el tomo cuarto, destinado a la picaresca, salió al cuidado de Bonilla y San Martín, quien se encargó de su edición siguiendo las instrucciones del polígrafo), su promesa no alcanzó a dar fruto alguno.

En cualquier caso, también Menéndez Pelayo, como Amezúa, estaba acentuando la necesidad de poner en marcha cuanto antes un estudio sobre la novela corta del seiscientos de objetivos y dimensiones semejantes a los del trabajo que Caroline B. Bourland (1905) llevó a término sobre la influencia de Boccaccio en la novelística española. Interesada por la literatura castellana heredera del Decamerone, tras su excepcional monografía, que finalmente no logró completar y refinar Menéndez Pelayo, Bourland (1927) se dedicó a preparar un catálogo bibliográfico sobre la novela corta española; en los primeros apartados de este nuevo estudio, la crítica norteamericana (1927: 11) puso de relieve la decisiva influencia de los novelistas italianos, y destacó que

The followers of Cervantes frequently carried their indebtedness much farther. The found in the novelle of Italy not only models of form but an inexhaustible supply of plots, and looking upon their authors as masters in the art of story writing, again and again, in Prefaces and Introductions, expressed their admiration for them, while in the tales themselves they repeatedly used Italian themes.

Sin embargo, en el siglo que ha transcurrido desde las palabras de Menéndez Pelayo, aún no se ha acometido la labor de indagar en un estudio unitario la proyección de la novelística italiana del cuatrocientos $y_{1}$ fundamental- mente, del quinientos en la española del seiscientos. Los resultados de estas relaciones de dependencia con los que contamos han llegado a constituirse aislada, incompleta y desproporcionalmente, de forma que tenemos dispersos apuntes y notas sobre la influencia de Bandello en Lope o de Straparola en Castillo Solórzano, pero ni pueden entenderse como fragmentos definitivos o acabados del nonato estudio panorámico, ni menos aun puede concluirse de forma apresurada y sinóptica que la influencia llegó desde un par de autores italianos y recayó solo sobre unas cuantas obras.

Pero si lejos estamos todavía de poder revelar la verdadera filiación que existe entre las novelas de Lope de Vega, Castillo Solórzano, Lugo y Dávila o Sanz del Castillo, y las de Grazzini, Straparola, Parabosco, Doni, Bandello, Masuccio o Giraldi Cinzio, no menos alejados estamos de un exacto conocimiento de la difusión en España de los novellieri que llegaron a ser traducidos. Menéndez Pelayo pasó casi de puntillas sobre los continuadores de Boccaccio que fueron volcados al castellano. Sin embargo, en sus ligeras anotaciones, reparó en un aspecto de notable interés; me refiero a la cuestión centrada en la introducción de los novelistas italianos en España en un momento en el que nuestros escritores parecian no haber aceptado la nueva fórmula propuesta por Timoneda y tampoco manifestaban inclinación alguna por componer colecciones de novelas $a$ la toscana. Si Amezúa (1982 [1956]: 247), en su panorama sobre la novela corta que precedió al tomo de su edición de las Novelas ejemplares de Cervantes, ya había incidido en que fueron "nuestros editores y libreros" quienes adivinaron "codiciosamente la suma de ganancias que traían consigo las novelas italianas" y no tardaron en buscar "traductores" que las trasladasen "a nuestro idioma", Menéndez Pelayo (1943 [1910]: 41-44) se le había adelantado al apuntar que

casi siempre eran tipógrafos o editores versados en el comercio de libros y en relaciones frecuentes con sus colegas (a las veces parientes) de Italia y Francia los que introducian entre nosotros estas novedades de amena literatura, desempeñando a veces, y no mal, el papel de intérpretes, aspecto muy curioso de la actividad intelectual del siglo XVI.

Sin embargo, la cuestión, que ahí se iluminaba parcialmente, revisada con más pormenor ha de ser reconsiderada en otras facetas. Según mis propias indagaciones en el 
conjunto del material sometido a numerosas calicatas, algunos de los traductores en los que más adelante me centraré decidieron motu proprio, sin intermediar acuerdos con libreros o impresores, difundir en nuestra lengua determinadas obras que en Italia habían generado una gran expectación. Por tanto, la labor de estos traductores, en el marco de una España que iniciaba la trayectoria de la narrativa breve del último cuarto del siglo XVI de manera titubeante, fue mucho más decisiva de lo que hasta ahora se ha podido decir. Como se verá, en el siglo que ha transcurrido y que nos separa de las palabras de Menéndez Pelayo, la crítica, por lo general, en sus acercamientos a esta etapa decisiva en la historia de la novela en España, no ha asumido sino muy parcialmente la responsabilidad de abordar con el detenimiento que merece los diferentes episodios y espacios de creación y difusión editoriales que comprende el asunto.

Aunque se ha acudido en innumerables ocasiones a los textos que traigo ahora a estas páginas, me parece pertinente que aqui se retomen algunas de las citas que nuestros novelistas del XVII reiteraban en los prólogos de sus obras para corroborar la fortuna de los novellieri y, de algún modo, saldar la deuda que con ellos tenían (aunque a veces esto último lo hiciesen precisamente empleando argumentos $a$ contrario sensu). Pese a que Cervantes, en las páginas preliminares de sus Novelas ejemplares (1613), insistió (en ese mensaje mesiánico que viene a ser casi una tópica en los prólogos cervantinos) en haber sido "el primero" en novelar "en lengua castellana"2, recordaba exprofeso "que las muchas novelas que en ella andan impresas todas son traducidas de lenguas estranjeras". Con meridiana voluntariedad, Cervantes no echó cuentas de las novelas intercaladas en la primera parte del Guzmán de Alfarache, ni tampoco quiso acordarse en ese momento de las cuatro novelas que se narran en las noches invernales de carnestolendas en la obra de Antonio de Eslava, y que vieron la luz en 1609. Sólo reparó en la cantidad (muchas) de novelas impresas y en su naturaleza (traducidas de lenguas estranjeras).

No obstante, en su prólogo hay también varios guiños al lector que no pasan desapercibidos. Al justificar el calificativo que utilizó en su título, estaba parafraseando la combinatoria defendida por Horacio (modelo, por cierto, al que también se acogió la amplia mayoría de novelistas) de deleitar y aprovechar a un mismo tiempo. Decía (2001: 18) que su "intento" había sido el de
[...] poner en la plaza de nuestra república una mesa de trucos, donde cada uno pueda llegar a entretenerse, sin daño de barras; digo, sin daño del alma ni del cuerpo, porque los ejercicios honestos y agradables antes aprovechan que dañan. Sí, que no siempre se está en los templos; no siempre se ocupan los oratorios; no siempre se asiste a los negocios, por calificados que sean. Horas hay de recreación, donde el afligido espíritu descanse.

Los términos remarcados, selectivamente escogidos por Cervantes, no disimulan su pretendida filiación con varios de los títulos con los que corrieron algunas traducciones de los novellieri. La obra de Straparola, por ejemplo, según la traducción de Truchado, llevaba estampado en su frontispicio Honesto y agradable entretenimiento, mientras que la de Guicciardini, en su edición bilbaína, se difundió con el título de Horas de recreación. Estas reminiscencias, colocadas en un lugar del libro tan emblemático y programativo como el prólogo, evidencian la necesidad de Cervantes por presentar una obra que, por el título y las palabras preliminares, el lector identificaría fácilmente y catalogaría en ese género importado de Italia que empezó a proliferar en España a finales del siglo anterior. No es ocioso recordar en este sentido que

cuando Miguel de Cervantes solicita del Rey por conducto de su Consejo de la Cámara la concesión del Privilegio para los Reinos de Castilla, los doce cuentos llevan por título Novelas exemplares de honestíssimo entretenimiento. Este mismo rótulo se repite en la petición del Privilegio para los reinos de la Corona de Aragón, en la Aprobación de Salas Barbadillo y en la escritura de venta a Francisco de Robles (Amezúa, 1982 [1956]: 557).

Fue Amezúa (1982 [1956]: 557-558) quien planteó algunos interrogantes sobre el cambio de título a última hora. En uno de ellos reparaba en la posibilidad de que Cervantes quisiese evitar la coincidencia con "la traducción castellana de las novelas" de Straparola, pues "la primera parte del título -seguía diciendo Amezúa-, Novelas ejemplares, recordaba el de la versión castellana de la del Bandello. ¿Pareció a Cervantes en un principio que, tomando palabras de uno y de otro, cabía dar a su libro un rótulo sonoro y significativo?". Además de las razones literarias, es palmario que Cervantes quería asegurarle a su obra una proyección a la búsqueda del éxito inmediato, colocándole un título que sólo con el término novela se 
emparentase con un género de consumo en Italia que en el mercado del libro español había conocido a fines del XVI una asombrosa eclosión.

Con diferente tono, más explícito para lo que nos interesa y quizá también más elocuente, en la apertura de su novela Las fortunas de Diana, incluida en La Filomena (1621), Lope de Vega (2007: 45-47) mostraba su obediencia a la señora Marcia Leonarda, quien le había mandado escribir "una novela", y expresaba la "novedad" que para un hombre de teatro había representado componer una pieza de tal "género y estilo, más usado de italianos y franceses que de españoles". En un introito a modo de breve panorama de la novela corta, provisto de ciertas ironías dirigidas contra Cervantes, Lope recordaba que en España también se habían difundido los

\begin{abstract}
[...] libros de novelas, dellas traducidas de italianos y dellas propias, en que no le faltó gracia y estilo a Miguel Cervantes. Confieso que son libros de grande entretenimiento y que podrian ser ejemplares, como algunas de las Historias trágicas del Bandelo, pero habian de escribirlos hombres científicos, o por lo menos grandes cortesanos, gente que halla en los desengaños notables sentencias y aforismos.
\end{abstract}

Antes de Lope, Lugo y Dávila, en su Teatro popular (1620), a través de uno de sus dialogantes, recalcó (en Bonilla Cerezo, 2011: 57-58) el ingente "número de novelas" que habian compuesto y editado "los italianos", sentenciando que bien "pudieran excusarnos hacer nuevas imaginaciones y inquirir nuevos sucesos"; aunque Lugo y Dávila, al igual que Lope, marcó algunos hitos en la historia de la novela (que para él, según las denominaba, era un "género de poemas"), remontándose desde las obras de Heliodoro, Teágenes y Cariclea, y Aquiles Tacio, Leucipa y Clitofonte, era más explícito al reconocer en la tradicion española ("en nuestro vulgar" idioma) piezas de este género en obras como "el Patrañuelo, las Historias trágicas" de Bandello, las Novelas ejemplares de Cervantes "y otras muchas". Las citas de Lope de Vega y Lugo y Dávila recalcan algo que no por apodíctico en una perspectiva de historia in praesentia debe ser silenciado: a la altura de los años veinte las colecciones de novelas italianas son un importante sedimento en la formación de los escritores españoles, que están enriqueciéndose, a través de sus originales o a partir de las traducciones, con la lectura de las historias de Bandello y otros autores.
La influencia de los novelistas italianos en España, de la que en un momento determinado todos se querian despegar, queda perfectamente reflejada en las contraindicaciones que dos autores, Pérez de Montalbán y Castillo Solórzano, colocan al frente de sus obras. En el prólogo de los Sucesos y prodigios de amor (1624), Montalbán (1992: 9) pedía al lector que agradeciese no "haber visto en la lengua italiana" ninguna de las novelas que presentaba; su reivindicación, enderezada a realzar la originalidad de su obra, idea arrastrada desde Cervantes y cada vez menos original en los prólogos de las colecciones de novelas, le condujo a asegurar que si había quienes pedian "a otras naciones pensamientos prestados" "para cosa de tan poca importancia" como era el componer novelas, él no pretendía incurrir en este "agravio" de "nuestra [lengua] y de sus ingenios".

Dos años más tarde, con la ley que prohibía publicar libros de novelas y cuentos en vigor (Moll: 1974; Cayuela: 1993, 2011), sale de la imprenta las Tardes entretenidas (1626) de Castillo Solórzano, quien, con las palabras de Montalbán bien leídas, pues las suyas parecen modularse como una justificada réplica ante las insinuaciones de aquél, afirmaba (1992: 8) igualmente "que ninguna cosa" de las que presentaba era "traducción italiana, sino todas hijas de mi entendimiento, que me corriera mucho de oír de mí lo que de los que traducen o trasladan, por hablar con más propriedad". Sin embargo, hay que colocar como telón de fondo explicativo que tanto Pérez de Montalbán como Castillo Solórzano tomaron como fuente de sus novelas las de algunos de los autores italianos más laureados (Laspéras, 1987: 96-99) ${ }^{3}$, con lo que sus afirmaciones pueden ser vistas al trasluz de ese adagio latino que nos recuerda que quien se excusa, se acusa.

Pese a la evidente relevancia que cobra la lectura de los novelistas italianos por parte de los autores españoles del XVI y, fundamentalmente, del XVII, la critica, como antes sostenía, no ha asumido todavía en su totalidad las proclamas que Menéndez Pelayo o Amezúa dictaron a principios del siglo XX; el tiempo transcurrido, más que suficiente para que el conocimiento de la difusión e influencia de los novellieri en España no fuese ya tan endeble y aleatorio, realza la necesidad de levantar de nueva planta ese espacio histórico-literario. No obstante, cabe decir, en honor a la justicia, que existen varios acercamientos específicos, algunos más acertados y mejor orientados que otros, que 
merecen un somero recordatorio. En un intuitivo ensayo, al que se le ha prestado poca atención, Julia Barella (1985: 26) reparó en "la curiosa confluencia" que en un momento de la historia literaria se produce "entre el carácter de las colecciones de cuentos, fábulas o relatos cortos medievales, las costumbres literarias que llevan consigo (lectura en voz alta, reunión en tertulia, conversaciones en torno a la chimenea...) y la rápida asimilación de la

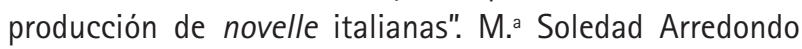
(1989) estudió en un breve artículo algunos aspectos de la versión "francoespañola" del texto de Bandello que se difundió en España, dejando constancia de ciertas coincidencias entre el prólogo de los traductores franceses y el que puso Millis al frente de su versión de las Historias trágicas ${ }^{4}$. De los autores traducidos, quizá ha sido Giraldi Cinzio el más estudiado. Como adelanto de su Tesis, Mireia Aldomà García (1996) participó en unas jornadas con una sucinta contribución sobre la versión castellana de Giraldi Cinzio. Aunque su trabajo doctoral (1998) es un estudio más completo (que se extiende en aspectos muy generales sobre la traducción, la censura o el contexto narrativo), en el que además editó la traducción que Vozmediano realizó de los Hecatommithi de Giraldi Cinzio, no agotó el campo de trabajo sobre la Primera parte de las cien novelas. Por las mismas fechas en las que aparecieron estas aportaciones de Aldomà García vio la luz el volumen catalográfico que Irene Romera Pintor (1998) realizó sobre la obra de Giraldi Cinzio, en el que clasificó la amplia obra del escritor italiano y desenredó algunas marañas bibliográficas que se habían creado en torno a ella ${ }^{5}$.

Sin embargo, es justo y necesario señalar que antecedió a la mayoría de estas contribuciones la insustituible historia de la novela en España en el Siglo de Oro de Jean-Michel Laspéras, cuyo mérito no ha sabido reconocerse como es debido; el estudioso francés le dedicó adensados encuadres a aquellos aspectos socioculturales más destacados que incidian sobre los novellieri traducidos al castellano. En numerosas notas diseminadas a lo largo de varios capítulos de su estudio destinados a los grandes mercados de libros españoles, a los índices de la Inquisición o al fenómeno de la traducción, Laspéras, con criterio y acierto, mostró el creciente interés que este capítulo de la historia de la novela en España tiene para varios campos de estudio que nuclean en torno a la sociología de la edición, llegando a abrir numerosos portillos que no fueron avistados ni por Menéndez Pelayo ni por Amezúa.
En este breve panorama que ahora presento me limito voluntariamente casi en exclusividad a lo puramente paratextual, porque, como se verá, desde los alrededores del texto puede atalayarse el enorme interés que encierra el grupo de obras aquí estudiadas. Trataré de condensar en este acercamiento, que a modo de preliminar quiere servir de antesala de una serie de aproximaciones que contemplo programáticamente en el marco de una empresa mayor, los aspectos que reúnan más interés relativos a los problemas bibliográficos y a las cuestiones derivadas de la traducción de aquellos novelistas italianos que fueron vertidos al castellano: Straparola, Guicciardini, Bandello y Giraldi Cinzio ${ }^{6}$. En el último de los apartados de este trabajo he tratado de aportar algunas sugerencias que, en forma de líneas de investigación, tienen la intención de desglosar un proyecto de trabajo que es necesario abarcar y desarrollar para poder reconstruir con suficientes garantías ese capítulo liminar de la historia de la novela en España que tiene como epicentro la difusión de los novellieri en España?.

\section{EN EL HORIZONTE EDITORIAL DE LOS NOVELLIERI}

\subsection{El Honesto y agradable entretenimiento de Straparola: todo problemas}

La obra de Giovan Francesco Straparola, la primera en ser traducida y editada en España, es sin duda la más sugestiva desde el punto de vista bibliográfico ${ }^{8}$. Fue Francisco Truchado quien se encargó de realizar la traslación al castellano de Le piacevoli notti, según rezaba su portada italiana, a la que dio por título Honesto y agradable entretenimiento de damas y galanes. La primera edición de la que tenemos hoy constancia fue impresa en Bilbao, a costa de Juan Ruelle, en 1580. Sin embargo, existen varios datos que han originado la creencia de que podría haber una edición anterior que no ha llegado hasta nosotros. La cédula real del Honesto y agradable entretenimiento fue expedida el 30 de septiembre de 1574, mientras que la eclesiástica se otorgó cuatro años más tarde. No era inhabitual que una obra tuviese que esperar varios años para ver la letra de molde; en unos casos los autores no lograban encontrar fondos de financiación para editar el libro o no ultimaban las negociaciones para vender la licencia de impresión; en otros casos, ya librada la licencia civil, los recelos de los miembros de la censura inquisitorial, que tenían que 
conceder el permiso eclesiástico, hacian que se retrasase la aparición pública de una obra.

Sin embargo, el caso de Francisco Truchado y su traducción de Straparola no se atiene al primero de los considerandos, pues tenemos noticia de un documento firmado el 7 de abril de 1576 por el cual el traductor traspasó, en la ciudad de Granada, "los derechos y licencia de impresión" a los editores Juan Díez y Francisco García:

Francisco Truchado, vecino de Baeza, traspasa en Juan Díez y Francisco Garcia, los derechos y licencia de impresión que tenía por diez años del libro titulado "Onesto y Agradable Entretenimiento" que él había traducido al castellano de la lengua toscana, a cambio de 12.000 maravedis y con el compromiso de recibir cien cuerpos de dichos libros de la primera impresión (Osorio, Moreno Trujillo y De la Obra Sierra, 2001: 534).

Pese a esta noticia de singular valor, los editores granadinos no llegaron a publicar la obra de Straparola hasta finales de 1582 (año marcado en la portada, aunque en el colofón se da la fecha de 1583). En el breve período que transcurrió desde la edición bilbaína de 1580 y el momento de la aparición de la edición granadina costeada por Díez y García, la Segunda parte del honesto y agradable entretenimiento se publicó en Baeza, en la casa de Juan Bautista Montoya y a costa de Antonio de Vega, en 15819; en la misma imprenta conoció dos reediciones más, en 1582 y en 1583 (Cátedra, 2001: 227-229 y 231-233). Por tanto, cuando los editores de Granada publican la primera parte del Honesto y agradable entretenimiento, no solo esta había visto la luz ya en Bilbao, sino que Truchado había culminado la traducción de la Segunda parte -cuya licencia vendió a un vecino de su tierra-, que se editó dos veces antes de 1582.

Los motivos de que Juan Díaz y Francisco García no hubiesen aventajado a todos los demás editores se desconocen, pero no es difícil imaginar que, adquiridos los derechos de impresión, o bien pudieron encontrar serios problemas para financiar el libro, u otros motivos comerciales les condujeron a tomar otra decisión de última hora. En cualquier caso, cuando estos editores granadinos se hacen con la licencia de impresión, en 1576, la obra no había obtenido aún la licencia eclesiástica, que se cursó en 1578, por lo que, cumpliendo con los criterios reglamentarios, no podía ser editada hasta entonces. Cedida la licencia de impresión, Truchado perdía los derechos de su traducción, así que tuvieron que ser los propios editores granadinos quienes negociaron con Juan Ruelle, que mandó imprimir el texto de Straparola en el taller de Matías Mares. La obra no llevaba estampado el privilegio (que sabemos que habia obtenido Truchado por tiempo de diez años), pero Díaz y García convendrian con Ruelle probablemente una venta de los derechos que no impidiese una salida futura en las prensas granadinas.

Además de estas cuestiones sobre los tratos que Truchado mantuvo con diferentes libreros, en torno a la princeps de la colección de novelas de Straparola planean ciertos interrogantes que aún esperan ser aclarados. En el "Parescer" que se imprimió en la edición de la Segunda parte del honesto y agradable entretenimiento, firmado el 9 de julio de 1581, Juan López de Hoyos (en Straparola, 1581: 270v) manifestaba que "agora doce años vi la primera parte, y con esta queda bien satisfecho a la promesa que el auctor hizo". De haber visto la luz doce años antes la primera parte de la traducción de Truchado, nos situariamos en el vértice de 1569, una fecha tempranisima en la que el traductor baezano habría visto impreso su trabajo con poco más de veinte años. Quizá haya una edición perdida, pero la documentación que tenemos (solicitud y otorgamiento de licencias, venta de privilegio) nos sitúan a mediados de la década de los setenta. Aunque imaginásemos, como hipótesis, que el cajista de la imprenta de Juan Bautista de Montoya cometió un error de lectura, entendiendo "doze" donde en el manuscrito ponía "dos", las fechas tampoco concordarian; si bien, y a falta de que se encuentre esta presunta edición perdida o algún documento que la ratifique, siempre podemos atribuir a malentendido (por parte del cajista) o despiste (por parte del censor) el dato aportado en ese documento impreso.

En el breve lapso de poco más de dos años, Straparola conoce al menos cuatro ediciones de su obra, una de la primera parte y tres de la segunda. Poco después de la fecha en la que aparecen las últimas ediciones del Honesto y agradable entretenimiento de damas y galanes comienza una serie de movimientos en la administración para solicitar licencias de impresión de otras traducciones que se habian preparado de algunos novelistas italianos que, como Straparola, estaban en la órbita de Boccaccio. Sin embargo, antes de llegar a ellos, hay un dato de interés 
extractado por Anastasio Rojo (1994: 157) y acentuado por Pedro M. Cátedra (2001: 241) que no puede ser pasado por alto. Truchado estaba interesado en prorrogar su privilegio original, otorgado en 1574 y concedido por un período de diez años (según sabemos a través del contrato firmado con los editores granadinos Díaz y García), para lo cual solicitó al Consejo una ampliación, que fue concedida el 3 de julio de 1586. Sabemos que con la expiración del privilegio, el contrato de cesión también finalizaba, por lo que lógicamente Truchado quiso renovar su exclusiva de edición para salvar su texto de posibles reediciones de las que él no podía beneficiarse. Esto llevó a Cátedra (2001: 241) a plantear la hipótesis de que hacia 1586, o quizá en algún año posterior, pudiese haber salido una edición de la primera parte del Honesto y agradable entretenimiento de damas y galanes. "No obstante -sigue diciendo Cátedra (2001: 245)-, teniendo en cuenta las relaciones de este traductor con varios libreros granadinos $y$, a su vez, la de éstos con otros impresores españoles, es posible que este privilegio fuera cedido para su explotación a otros". De la misma forma, Truchado consiguió un par de años más tarde la ampliación de su privilegio para la Segunda parte, lo que hizo pensar a Cátedra (2001: 245) que quizá estaba interesado en realizar "una nueva edición de la obra, que muy bien pudo ser de Baeza", hacia 1588, según sus barruntos ${ }^{10}$.

Sin embargo, por esas fechas en el panorama novelístico se habia presentado la obra de L. Guicciardini y se habian solicitado licencias de impresión para varias más (algunas de las cuales nunca llegaron a ver la luz), en las que más adelante me detendré. Por tanto, quizá Truchado encontrase, en un momento en el que el mercado editorial se estaba renovando, más dificultades para vender su privilegio. No obstante, transcurrida algo más de una década, por vez primera se editan conjuntamente las dos partes del libro de Straparola, concretamente en 1598, en Madrid, a costa de Luis Sánchez, a quien se le concede el privilegio de impresión un año antes. Algún tiempo después, en 1612, ve la luz en Pamplona, en casa de Nicolás de Asiaín, la Primera parte del honesto entretenimiento de damas y galanes; $y$ en ese mismo año la Segunda parte del honesto y agradable entretenimiento de damas y galanes. El número de ediciones que conoció la obra de Straparola fue verdaderamente espectacular, y el hiato que encontramos en los quince años que intermedian entre 1583 y 1598 se explica fácilmente por las nuevas traducciones que de otros novelistas italianos se estaban realizando. Sin embargo, en cuanto remitieron las traducciones de los novelistas italianos y sus ediciones escasearon en los fondos de los libreros, algunos editores no dudaron en acudir nuevamente a reeditar la obra de Straparola.

\subsection{Los hermanos Millis y su implicación en la difusión de la novella: Guicciardini, Bandello y Sansovino}

También en Bilbao, en la imprenta de Matías Mares (la misma que trabajó con el texto de Straparola y lo editó en 1580), a costa de Juan de Millis Godínez, salió en 1586, con el título de Horas de recreación, la versión española de L'hore di recreatione de L. Guicciardini, por Vicente de Millis Godínez, "traductor de esta obra", según se indica en el pie de la dedicatoria. Aunque la fecha de salida fue la de 1586, es preciso indicar que esta traducción parcial de la colección italiana fue realizada algunos años antes, pues en el estío de 1584 el librero Juan de Millis obtuvo la licencia y aprobación para editar la obra". Aunque no se pueda aportar una respuesta certera que dilucide el desfase temporal entre la concesión de la licencia (1584) y la impresión final (1586), las noticias provenientes de la documentación legal que contiene el texto nos sitúan en una fecha cercana a la eclosión de la traducción de Straparola, con lo que se deja intuir fácilmente que los hermanos Millis vieron en este género literario -que germinó por aquellos años y que había despertado rápidamente el interés de los lectores- un filón comercial a través del cual poder obtener grandes beneficios.

En 1588 ve la luz otra traducción de la obra de Guicciardini; no se trataba de una continuación de la que realizó Millis algunos años antes, sino de una nueva traducción sui generis de L'hore di recreatione, esta vez realizada por Jerónimo de Mondragón y titulada Primera parte de los ratos de recreación; esta se publicó en la imprenta zaragozana de Pedro Puig y Juan Escarrilla.

Juan Millis Godínez aparece nuevamente entrecruzándose en esta historia editorial que se está pergeñando de las traducciones al castellano de los novellieri; tres años después de costear las Horas de recreación de Guicciardini, traducidas por su hermano, Vicente de Millis, asumió los gastos de la traducción de las Novelle de Bandello, que salieron del taller salmantino de Pedro Laso en 1589. 
Aunque en ninguna parte se explicite quién realizó la labor de la traducción, parece natural que la llevase a cabo también Vicente de Millis Godínez, que es además quien firma la dedicatoria y compone el prólogo al lector (que, aunque en este caso no aparezca su nombre al pie del escrito, en cuanto al estilo no dista ni un punto del de la dedicatoria) ${ }^{12}$. Sin embargo, así como ocurriese con las Horas de recreación de Guicciardini, también a las Historias trágicas ejemplares, según el título de la traducción castellana, les fue concedida la licencia, el privilegio y la aprobación bastantes años antes de ser publicadas, en 1584.

Es sintomático que en un mismo año le fuesen otorgados a una misma persona los permisos de impresión para dos obras de autores italianos. Los Millis apostaron por la fórmula de éxito instaurada por Boccaccio y que en España estaba levantando cada vez más expectación a finales del $\mathrm{XVI}$, concretamente a partir de la puesta en circulación de la traducción de Straparola. En una fecha muy cercana a la aparición del Honesto y agradable entretenimiento en Bilbao, los hermanos Millis entendieron rápidamente que el camino de la narrativa, a falta de ingenios españoles que la cultivasen, pasaba por las colecciones de novelas italianas. Las dos ediciones que costeó Juan de Millis, aparecidas en 1586 y 1589, nos pueden llevar a pensar erróneamente que este editor pretendió medir los tiempos -controlando el mercado del libro- para distribuir la salida de dos traducciones de las que en un mismo año, 1584, había obtenido las licencias de impresión. Sin embargo, todo apunta a que las discordancias que existen entre las fechas de la solicitud de derechos de impresión y la publicación final no responden a estrategias comerciales, sino más bien a una férrea oposición por parte de los órganos censorios.

Esta sospecha se ve fortalecida cuando nos llega la noticia (Rojo Vega, 1994: 134) de que Juan Millis obtuvo la licencia, previa petición, "para la segunda parte de las Historias trágicas" en 1586, solo dos años después de haber conseguido la correspondiente autorización para la traducción que acabaría imprimiéndose en 1589. Este detalle nos indica que hubo una continuación de la obra de Bandello, probablemente también vertida al castellano por Vicente de Millis y que presuntamente quedó manuscrita, pues no tenemos constancia de esta edicón. Tampoco llegó a la imprenta (Rojo Vega, 1994: 149) "la primera parte de las cien novelas escogidas de Francisco Sansobino", obra para la que Juan de Millis también presentó su solicitud en 1584 al Consejo para obtener su licencia ${ }^{13}$.

Estos últimos datos de traducciones manuscritas para las que se pidió los derechos de impresión entre 1584 y 1586 y que nunca llegaron a ser editadas nos sitúan repentinamente ante un horizonte editorial de amplitudes y expectativas diferentes; si una primera aproximación a los archivos ha puesto al descubierto la existencia de dos colecciones de novelas traducidas y preparadas para la imprenta, quizá una investigación en profundidad de otra documentación que aún está por revisar pueda constatar la presencia de otras obras relacionadas con los novelistas italianos posteriores a Boccaccio para las que también se solicitaron licencias de impresión y nunca llegaron a la imprenta ${ }^{14}$. No hay que perder de vista que la impresión de una obra suponía un desembolso importante para el editor, pero cuando este se disponía a tramitar la solicitud de licencia al Consejo (gestión que también conllevaba unos gastos), tenía ya evaluado el interés del libro, su posible proyección y, naturalmente, el coste real que le podía suponer. Esto me hace pensar que seguramente el factor económico no fue determinante en muchos casos para que la obra no llegase a ser impresa; a mi parecer, las noticias ofrecidas por Rojo Vega son un claro manifiesto de que la censura (que, como se verá más abajo, intervino directamente sobre la mayoría de las traducciones) desempeñó un papel crucial en la puesta en circulación y el impacto de los novellieri en España.

Antes de terminar con la obra de Bandello, es preciso indicar que las Historias trágicas ejemplares se reeditaron dos veces más. La primera apareció en Madrid, en casa de Pedro Madrigal, a costa de Claudio Curlet, en 1596'. La siguiente, financiada por Miguel Martínez, se hizo sólo unos años más tarde, en 1603, y se compuso en la imprenta vallisoletana de Lorenzo de Ayala.

\subsection{Giraldi Cinzio: traducido y editado}

A finales de 1589 Gaitán de Vozmediano tenía ya traducida la obra de Giraldi Cinzio De gli Hecatommithi, a la que puso por título Primera parte de las cien novelas, y para la que le solicitó licencia al Consejo en diciembre de ese año (Rojo Vega, 1994: 134). Unos meses más tarde, y muy poco tiempo después de ver la luz el texto de Bandello, 
se imprime en Toledo, en el taller de Pedro Rodríguez y a costa de Julián Martínez, la última colección de novelas que fue editada en España.

\section{De censuras y tRaducciones}

De sobra es conocida la severa prescripción moral con la que se trató de enderezar cualquier aspecto tocante a lo social en el siglo XVI. Difícilmente la literatura que escapase al círculo de unos valores constituyentes podía tener cabida sin que la Inquisición no levantase su brazo y la obra fuese catalogada en los índices como prohibida o expurgada. En el caso de los novellieri, para Amezúa (1982 [1956]: 446-447) fueron "dos causas" las que

[...] impidieron que muchas de estas excelentes novelas no lograran entrar en España y, traducidas, servir de lectura grata y amena a cuantos ignoraban el idioma del Dante: una, su carácter libertino, licencioso y hasta obsceno; y otra, la libertad con que sacaban en sus relatos a frailes $y$ personas religiosas, o la forma en que hablaban de Roma y de su Curia. [...] La deshonestidad, pues, de muchas de estas novelas, y su intencionado o no anticlericalismo, impidieron su entrada en España y sus versiones castellanas. Mas tanta era la apetencia que el común de las gentes y las menos letradas sentían por esta clase de libros de pasatiempo, que, a la postre, adivinando la brava y rica mina que las novelas italianas contenían y las pingües ganancias que brindaban a quienes las tradujesen en castellano, algunos editores y libreros se decidieron por fin a hacerlo,

aunque con "cautelas y miramientos". De ahí que quienes apostaron en un momento determinado por difundir en España las colecciones de novelas italianas tuviesen que cuidar con muchas cautelas ciertos detalles para no darse un duro encontronazo con la censura. La fortuna con la que corrieron estas obras en Italia no era en modo alguno un patrón al que acogerse. El celo y la vigilancia que el Santo Oficio en España puso en el control del libro no es en absoluto comparable a la tolerancia que respecto a los temas profanos mantenían los órganos de censura en Italia. Los propios traductores y censores remarcaron la necesidad de aclimatar términos y dulcificar expresiones para que se aviniesen a la moral de catolicismo contrarreformista que imperaba en España.
Probablemente a causa de estas diferencias, los dos ejemplos de traducciones italianas a los que antes me referi no lograron superar su estado manuscrito, pese a que les fueron concedidas las pertinentes licencias reales; seguramente otras obras próximas genéricamente a Bandello y Sansovino, y de las que hoy no tenemos noticia, nunca obtuvieron la necesaria licencia eclesiástica para poder ser impresas. Juan de Millis evitó tener que comprar licencia alguna, pues fue seguramente su propio hermano quien se ocupó de traducir la segunda parte del libro de Bandello y también del de Sansovino; en cambio, aquellos mercaderes de libros que habian arriesgado demasiado al adquirir la licencia de una obra (de la que intuían podía ser beneficiosa) y después no obtenían el permiso eclesiástico, poco podían hacer más allá de intervenir en los títulos -parte del libro en las que ellos iniciaban su estrategia comercial-, en los que colocaban términos que denotaban el carácter ejemplar de la obra, aunque tal argucia no siempre podía resultar eficiente.

No obstante, antes de que los editores arriesgasen su hacienda, los traductores se habian encargado de preparar un material en el que habian tratado de asear los textos originales de toda palabra picante o escena impúdica. Ellos sabian que determinados episodios novelescos podian azorar a cualquier censor, y tampoco desconocian que determinados usos lingüísticos debían ser acomodados a la onestà que exigía la lengua española. Si no acometían esta primera labor de revisión y corrección, podian encontrar serias dificultades para vender la licencia a algún editor o para conseguir ellos mismos el permiso eclesiástico que ordenaba la ley. En los prólogos y las dedicatorias los traductores dejaban constancia de aquellas decisiones que habian adoptado con ciertas novelas, justificaban las modificaciones estilísticas o defendian las diferentes intromisiones en el texto, pero las correcciones posteriores que llevaron a cabo los censores, según se deja leer en las aprobaciones, ponen en tela de juicio la rectitud con la que aseguraban haber obrado los traductores, o al menos son un indicativo de que desde el Consejo se interpretaba con más restrictivo rasero los textos de entretenimiento.

\subsection{Francisco Truchado y López de Hoyos: "censores" de la obra de Straparola}

En el escrito que dirigió "al discreto y prudente lector" del Honesto y agradable entretenimiento, Truchado (en 
Straparola, 1580: 5v) explicaba que si en su traducción se hallaban "algunas partes" con un "sentido diferente", lo habia hecho

[...] por la necesidad que en tales ocasiones debe usar, pues bien sabéis la diferencia que hay entre la libertad italiana y la nuestra, lo cual entiendo será instrumento para que de mí se diga que por enmendar faltas ajenas saco en público las mias; por tanto prudentísimo lector, suplico os las corrijáis, y amigablemente enmendéis, porque mi voluntad y deseo fue acertar con la verdadera sentencia, y que vos, escardando estas peregrinas plantas, cogiésedes de ellas sus morales y virtuosas flores.

Truchado deja notar que tuvo que trabajar movido entre la obligación de honestar la lengua española y la intención de ofrecer un ramillete de avisos y enseñanzas. Sin embargo, a pesar de las presuntas transformaciones que sufrió el texto de Straparola en manos de su traductor baezano, al parecer de Amezúa (1982 [1956]: 449, n. 1) Truchado no logró totalmente poner en estilo "puro y casto" las libertades novelescas del autor italiano,

[...] porque, por ejemplo, la Novela $V$ de la Primera noche, la IV de la Tercera y la $V$ de la Quinta desarrollan argumentos y episodios bastante libres. La Novela III de la Cuarta noche versa sobre unas burlas, más que irreverentes, que se hacen a los frailes de un convento, y que prueba una vez más lo tolerantes que la Inquisición y la censura españolas eran para estas demasias antifrailescas, que tampoco causaban escándalo alguno.

En todo caso, parece que en la segunda parte Truchado no obró tan lícitamente como aseguraba en la primera. Al censor de la continuación traducida, Juan López de Hoyos (en Straparola, 1581: 270v-271), no terminaron de agradarle ciertos términos escogidos, ni aún menos partes completas en las que se trataba sobre ciertos enigmas de la ciencia, por lo que intervino directamente sobre la traducción que le llegó -que ya había superado el primer nivel de control, el del traductor-, declarando en su imprimatur lo que sigue:

No hallo en él cosa que no sea muy gustosa y de buen ingenio. Van borradas algunas palabras por no proprias, 0 no castas, algunos renglones enteros, particularmente en las Tropelias, que son experiencias o secretos de ocultas
Philosophías, en las cuales decian que se esperasen signos o planetas; para quitar supersticiones que dañan y ofenden en gran manera, con borrarlo queda lo demás conforme a su título de Honesto entretenimiento; y ansí van borradas de modo que el impresor vea luego lo que va con censura.

No reparó en otra cosa que no fuesen voces sueltas $y$, a su entender, malsonantes, aunque principalmente enmendó aquella parte que difundia ciertas creencias ocultas. La Inquisición se ocupaba de vigilar muy de cerca esos libros de arte adivinatoria, obras que se entendian como heréticas y que podían poner en riesgo el control ideológico que se pretendía ejercer sobre el pueblo. A López de Hoyos, en consonancia con una de las reglas del nuevo Índice que se estaba preparando (el decretado por Quiroga y que aparecería finalmente en 1583, una fecha muy próxima a la salida de esta Segunda parte de Straparola) le preocupaba mucho más las partes tocantes a las "ocultas filosofías" de la traducción que esos otros episodios novelescos de la primera que tanto enojaron a Amezúa.

Además de las palabras justificativas de su labor como traductor, que concluyen con una moralina final con la que trataría de congraciarse con los censores, cuya aprobación, con expurgaciones, ya habrian otorgado, Truchado (en Straparola, 1580: 5v-6) rebasó los límites de su quehacer al admitir que se atrevió "a hermosear este honesto entretenimiento con estos últimos y ajenos versos de divino juicio compuestos". La lectura de estas rimas incluidas hizo levantar quejas a Menéndez Pelayo (1943 [1910]: 40, n. 1), que los tachó de "detestables", porque "los enigmas del original [...] ofrecen casi siempre un sentido licencioso" que Truchado nunca trató de captar. Esta idea del traductor convertido en reescritor sugiere que en ocasiones tales intérpretes alteraron a capricho, y sin la necesidad de advertirlo, diferentes partes del original, sustituyéndolas por episodios sacados de su inventiva. Será el aragonés Jerónimo de Mondragón quien evidencie hasta qué punto un traductor podía tomar una obra no para traducirla, sino para recrearla.

\subsection{Vicente de Millis y Jerónimo de Mondragón, traductor y reescritor de L'hore di recreatione}

Para Amezúa (1982 [1956]: 451), L'hore di recreatione era la que revestía menos complejidades de traducción, porque L. Guicciardini pertenecía "a la clase de novelistas que 
escriben después del Concilio de Trento y de la reacción católica y moralista que éste trajo consigo, reprimiendo con mano firme toda aquella literatura licenciosa y anticlerical, atizadora de vicios, surgida en pos de Boccaccio". Quizá esta razón pudiera ser la que propició que la obra del escritor italiano hubiese encontrado dos traducciones diferentes al castellano. Sin embargo, atendiendo a las amonestaciones del censor de la versión realizada por Vicente de Millis, el primer traductor de L. Guicciardini, se advierte que el original de L'hore di recreatione no era apto para circular traducido al castellano sin una revisión previa. Lucas Gracián Dantisco (en Guicciardini, 1586: 2), que aseguraba haber "conferido con su original, impreso en Venecia", el texto traducido por Vicente de Millis, admitía que, "para que vaya más casta la lectura", había "testado algunas cosas que van señaladas y emendado otras, sin las cuales lo demás puede pasar". Por tanto, la versión que apareció impresa fue una traducción "castigada" de la obra de Guicciardini.

Jerónimo de Mondragón fue quien preparó la nueva traducción del texto de Guicciardini, que sin duda se presenta, desde el enunciado de su título, más interesante que la anterior: Primera parte de los ratos de recreación [...]. Traducidos de lengua italiana y añadidos otros muchos que se han puesto en lugar de algunos que se han dejado de traducir por ser de poco provecho, e ilustrados con muchas autoridades de poetas y otros graves escritores griegos, latinos, españoles, italianos y franceses por el licenciado Jerónimo de Mondragón [...]. No tenemos una continuación de la labor iniciada por Vicente de Millis, como quizá cabría esperar, sino una nueva traducción parcial, o más bien, una adaptación de la obra de Guicciardini. En su extenso prólogo, Mondragón (en Guicciardini, 1588: 17) justificaba con pormenor las adiciones, omisiones y sustituciones que había llevado a cabo en el texto del italiano, y aclaraba que todas las novedades habian sido señaladas "con una estrella puesta en la margen". Por tanto, siguiendo esta indicación de Mondragón, no sería necesario que confrontásemos el texto original con esta traslación para comprobar cuáles fueron esas partes añadidas, pues su responsable se había encargado de marcar en los ladillos del texto aquellas adiciones que alteraban el original. Sin embargo, Aldomà Garcia (1998: 321) detectó algunos agregados, referidos a aquellos lugares donde "los cambios en la traducción obedecen a razones de censura", sobre los que Mondragón no llamó la atención, lo que sugiere que la versión española pudo distanciarse desde el punto de vista estético bastante con respecto a su original italiano.

En otro sentido, el traductor aragonés se defendía de los posibles ataques alegando que había obrado de esta forma porque la obra de Guicciardini era un conglomerado de historias menores, cuya esencia no se veía afectada por sus intromisiones. Curiosamente, en ese pliego de descargo que hacía Mondragón previniendo los posibles reproches, declaraba (en Guicciardini, 1588: 17v), contra quienes advirtiesen la poca novedad del texto traducido, que "jamás se vio en esta lengua y con semejante estilo" tal obra. Aunque sospecho que el traductor quería infundirle a esta frase un sentido que apuntaba a la novedad del contenido, y acudia al conocido proverbio que reconoce que prácticamente todo está ya declarado en la tradición, es interesante que manifieste con absoluta rotundidad que en nuestra lengua nunca se vio tal obra, cuando dos años antes había sido publicada en Bilbao.

Difícilmente a Mondragón se le habría escapado la traducción de Millis, de la que a ojos vista se quería apartar. Con cierta industria, no la citó en su prólogo, o si acaso lo hizo de forma velada y por omisión ("jamás se vio en esta lengua y [jamás se vio] con semejante estilo"), y evidentemente optó por un título diferente. Cuando escogió hacer una traducción literal del original, Mondragón comenzó por rechazar el término rato y remarcó que se trataba de una primera parte. En el cierre de su prólogo, Mondragón, acudiendo a un tópico del exordio, prometía (en Guicciardini, 1588: 18) que si esta parte "cayere en gusto", estaba dispuesto a componer "la segunda o añadir esta con cosas de no menor curiosidad y entretenimiento; y si no, quedarse han, como dicen, en el saco para otra mejor feria". Tuviese o no ideada, o incluso en preparación, una continuación o una edición revisada y ampliada, lo cierto es que estas palabras parecen más bien un intento de sobreponerse a la traducción de Millis e invitar al lector a que el texto completo de Guicciardini sólo lo podría tener asegurándose esta primera parte que, con la aceptación del público, sería continuada.

\subsection{Las novelas afrancesadas de Bandello}

En el título de la obra con el que corrieron las novelas de Bandello (1589) por las librerías españolas se precisó que habian sido "nuevamente traducidas, de las que en 
lengua francesa adornaron Pierres Bouistau y Francisco de Bellaforest". No es necesario comprobar la traducción con su original para concluir que no se llegó a tomar un texto italiano como base de la traducción, sino que quien realizó esta labor se valió de la versión difundida en Francia por los autores citados, quienes al parecer de Menéndez Pelayo (1943 [1910]: 35) "habían estropeado el texto con fastidiosas e impertinentes adiciones". En su dedicatoria, Vicente de Millis se extendió sobre la ejemplaridad de la "Historia", esa disciplina que, en palabras de Cicerón,

[...] tiene por oficio manifestarnos las cosas pasadas, instruirnos en las presentes y aprovechar con su ejemplo en las futuras. Y lo principal en que se ocupa es en ponernos delante personas illustres y señaladas, cuyos hechos y vidas fueron trabajos dignos de mucha honra y alabanza, para que viendo esto los presentes y los porvenir, y considerando que los hechos heroicos permanecen siempre en la memoria de los hombres, se animen a emprender cosas semejantes.

Toda esta explicación, a la que le siguen más argumentos en esta dirección, le sirvió a Millis (en Bandello, 1589: 4$5 \mathrm{v})$ para engrandecer esas pequeñas "historias" compuestas por Bandello, quien "recogió muchas y muy notables, unas acontecidas en nuestra edad y otras poco antes, queriendo en esto imitar a algunos que tuvieron por mejor escribir lo sucedido en su tiempo [...] que volver a referir los hechos antiguos", y compararlas con la enseñanza que podian aportar al lector. Después de elogiar la lengua y el estilo del novelista italiano, quien según Millis escribe "con toda llaneza y fidelidad, sin procurar afeites ni colores retóricos que nos encubran la verdad de los sucesos", expuso el motivo de la selección que había realizado: "escogí catorce, que me parecieron a propósito para industriar y diciplinar la juventud de nuestro tiempo en actos de virtud y apartar sus pensamientos de vicios y pecados". Aclaró asimismo haber elegido como modelo a los traductores franceses porque a su parecer ellos pusieron las novelas "con más adorno y en estilo muy dulce y sabroso, añadiendo a cada una un sumario con que las hacen más agradables y bien recebidas de todos". Amparándose, por tanto, en la lección que estas historias pueden producir "a nuestra nación", y en "que no hay lengua vulgar en que no anden escriptas", "quise -sigue diciendo- saliesen a luz en la nuestra, para que en ella no faltase cosa de que podría resultar tanto provecho y utilidad".
Sobre los mismos argumentos volvía en la dedicatoria al lector (en Bandello, 1589: 6), pero matizó algo que no puede pasarse por alto; aseguraba que, pese a que tomó la decisión de seguir la traducción francesa, que elogiaba y encarecia, sin embargo se vio en la obligación de limar, según sus propias palabras, algunos aspectos de lengua, "añadiendo o quitando cosas superfluas y que en el español no son tan honestas como debieran, atento que la francesa tiene algunas solturas que acá no suenan bien. Hallarse han mudadas sentencias por este respeto y las historias puestas en capitulos, por que la lectura larga no canse". No descarto que este argumento fuese confesado a posteriori, es decir, tras la expurgación del censor, Juan de Olave, cuya aprobación entregaría sin leer los textos introductorios. Aunque Olave (en Bandello, 1589: 3v) terminó dando su parabién a la obra de Bandello, que contenía "muchos y muy buenos ejemplos de moralidad", sin embargo censuró "algunas maneras de hablar algo desenvueltas que en la lengua francesa, donde está más extendido, debe permitirse y en la nuestra no suenan bien; y así las he testado y enmendado otras".

Con la colección de Bandello no sólo tenemos el reconocible caso de doble filtro que nos hemos encontrado con los autores anteriores, sino que hay que agregar un tercer nivel de control que interfiere directamente sobre el contenido de la obra. Por tanto, la versión española de las novelas de Bandello, desde este presupuesto, será notablemente distinta a la versión que hicieron los intérpretes franceses, que a su vez moldeaba el original que salió de la pluma del escritor italiano.

\subsection{Gaitán de Vozmediano: instigador de la novela corta}

La obra de Giraldi Cinzio encontró un traductor que pareció querer darle un impulso decisivo a la novelística española. En su prólogo, Gaitán de Vozmediano (en Giraldi Cinzio, 1590: 4-5) comentaba la variedad temática de la obra de Giraldi Cinzio, destacando, como hizo Millis, la verosimilitud y ejemplaridad de sus cuentos. Si bien, precisaba este último término escogido, porque a su parecer son "honestos"

[...] respecto de los que andan en su lengua, que para lo que en la nuestra se usa no lo son tanto que se permitieran imprimir sin hacer lo que se ha hecho, que fue, quitarles lo que notablemente era lascivo y deshonesto. Para lo cual hubo necesidad de quitar cláusulas enteras, y aún toda una 
novela, que es la segunda de la primera Década, en cuyo lugar puse la del Maestro que enseña a amar, tomada de las ciento que recopiló el Sansovino. Esto y otras cosas semejantes hallará quitadas y mudadas el que confiriere la tradución con el original, especialmente el saco de Roma, que se quitó por quitar algunos inconvenientes que pudiera[n] seguirse de imprimirle.

Volvemos a tener una traducción que se atuvo poco a su original en cuestiones de estilo; pero además Vozmediano se vio en la obligación moral, según confiesa, de sustituir una de las novelas del original por otra de Sansovino. Era evidente que lo que Giraldi Cinzio podría decir del saco de Roma y de la figura del emperador Carlos $V$ en poco se asemejaría a lo que en España se pretendía difundir de esos acontecimientos. Sin embargo, y pese a las palabras justificativas de Vozmediano, esta parte del expolio de Roma se tradujo en primera instancia, pues Tomás Gracián Dantisco, en su censura, concedió que se podía "dar el previlegio y licencia pedida" siempre y cuando se eliminase "el primer cuaderno del saco de Roma por algunos respectos de consideracion". Parece evidente que Vozmediano quiso de algún modo congraciarse con el Consejo y disculpar su grave desliz.

A los argumentos expuestos por Gaitán de Vozmediano, le siguen otros no menos interesantes referentes a los motivos que le alentaron para realizar su traducción. Para Vozmediano, además de que la obra de Giraldi Cinzio reunía "gusto y entretenimiento", no había "en nuestra lengua cosa deste subjeto que sea de importancia, pues son de harto poca los que llaman entretenimientos de damas y galanes". El traductor claramente estaba preparando un labor contrapropagandística, aludiendo sin disimulos a la obra de Straparola, un best seller que hasta ese momento había conocido más ediciones que ningún otro novelista. Comparaba las "Novelas de Juan Bocacio, que un tiempo anduvieron traducidas", con las de Straparola, alegando sin contemplaciones que de unas a otras "va [...] lo que de oro terso y pulido a hierro tosco y mal labrado". En su intento por avivar el enteco panorama de la novela corta en España, recordaba que "ahora también han salido algunas de las Historias Trágicas traducidas de francés, que son parte de las Novelas del Bandelo, autor italiano, y no han parecido mal". Sin embargo, entendía

[...] que ya que hasta ahora se ha usado poco en España este género de libros, por no haber comenzado a traducir los de
Italia y Francia, no solo habrá de aquí adelante quien por su gusto los traduzca, pero será por ventura parte el ver que se estima esto tanto en los extranjeros para que los naturales hagan lo que nunca han hecho, que es componer novelas. Lo cual entiendo harán mejor que todos ellos y más en tan venturosa edad cual la presente, en q[ue] como vemos tiene nuestra España no un sabio solo, [...] sino millares dellos cada ciudad que la ilustran y enriquecen. Entretanto, yo, que he dado principio a la traducción de esta obra del Giraldo, la iré prosiguiendo hasta el fin, si viere que se recibe co[n] el gusto y el aplauso que el ingenio de su auctor pide y mi trabajo y voluntad merecen.

¿No era consciente Vozmediano de que hacía una década se habían "comenzado a traducir" y editar libros de "Italia y Francia"? Del francés, lengua de la que se habían tomado las novelas de Bandello, provenía la edición de las Historias prodigiosas y ejemplares, una compilación elaborada por los franceses Boiastuau, Belleforest y Tesserant que fue traducida por el impresor sevillano Andrea Pescioni y que, colocada en un subcapítulo, habría que sumar a las ediciones aparecidas en la década de los ochenta de los novelistas que fueron traducidos del italiano ${ }^{16}$. Por tanto, conociendo que Vozmediano se había referido casi sin embozos al libro de Straparola y había reconocido la aparición de la obra de Bandello, no se puede pensar que quisiese taimadamente con estas palabras encubrir una realidad editorial de la que difícilmente podía rehuir cualquier lector de la época. Quizá, por tratar de buscar una explicación coherente a lo expresado, querría referirse a que se había iniciado con cierta timidez la traslación de algunos libros, pero que aún no se habían "comenzado a traducir los de Italia y Francia" masivamente. En cualquier caso, y ante las dificultades interpretativas que plantea el busilis de esta cuestión, se advierte a las claras que la intención última de Vozmediano estaba puesta en avivar el genio de los escritores españoles, a los que animaba con fervor a introducirse en un campo prácticamente en barbecho como era el de las "novelas".

\section{UN ESLABÓN PERDIDO EN LA HISTORIA DE LA NOVELA: LA DÉCADA DE LOS NOVELLIERI}

En el amplio y rico panorama que se abre en la narrativa del siglo XVI, resulta sustancial, en un momento de con- 
vivencia entre diferentes tendencias novelísticas, situar las traducciones de los novellieri italianos. Mientras poco antes un librero había tanteado las novelas del toscano y había comenzado a publicar algunas colecciones de relatos en los años sesenta ${ }^{17}$, en la segunda mitad del siglo XVI los editores estaban apostando por géneros de ascendencia grecolatina como la novela pastoril (en 1560 aparece la Diana de Montemayor, que es secundada por la Diana enamorada de Gaspar Gil Polo, publicada en 1564; algo más de veinte años después se imprimió La Galatea de Cervantes, en 1585) o la novela griega (la Selva de aventuras, de Jerónimo de Contreras, ve la luz en 1565); pero también seguian publicando originales de aquellas afamadas historias de caballerías que desde finales del XV habian supuesto para la imprenta un verdadero revulsivo editorial (aún se continúan publicando obras como el Olivante de Laura de Torquemada, en 1564, o algunos años más tarde el libro de Esteban Corbera Febo el Troyano, 1579); editaban igualmente otros géneros que durante un largo período habían gozado del favor del público como el diálogo (Diálogo en laude de las mujeres, 1580, de Espinosa; De los nombres de Cristo, 1583, de fray Luis de León, o los Diálogos familiares de Pineda, 1589) o la miscelánea (Jardín de flores curiosas, 1570, de Torquemada). En cambio, las colecciones de cuentecillos, facecias o apotegmas, como las de Mal Lara, Filosofía vulgar, 1568, o Juan Rufo, Las seiscientas apotegmas, 1596, no parecieron despertar en su momento una gran expectación, seguramente porque este tipo de narraciones breves, según anotó A. Prieto (1986: 351), se recogen durante esta época, "como animación o contrapunto, en otros sistemas literarios de mayor extensión". Sólo la Floresta española, 1574, de Melchor de Santa Cruz tuvo numerosas reediciones a lo largo de su época.

Sin embargo, el género que en Italia estaba dominando la prosa novelística no había comenzado a cultivarse en España; cuando Francisco Truchado ve la oportunidad de traducir a Straparola conocería la fortuna editorial de los novellieri en Italia (y en particular de Le Piaccevoli notti), y desde luego no podía ignorar las relaciones literarias que existian entre la obra que pretendia traducir y el Decamerone de Boccaccio (autor cuyas traducciones habian tenido un enorme éxito en castellano), y probablemente también sabría que varias obras suyas -entre ellas el propio Decamerone- habian sido incluidas por la Inquisición en el Índice de libros prohibidos de $1559^{18}$. Además de su apego por la literatura de entretenimiento, estas circunstancias editoriales de Boccaccio y sus seguidores ayudarían a que Truchado resolviese traducir una obra que estaba siendo objeto de numerosas reediciones en Italia; lo hizo además en un momento transitorio en el que la propuesta de novelar el cuento de Timoneda ${ }^{19}$, imitando, adaptando o versionando narraciones y novelas recogidas de la tradición oral y escrita, no parecía haber obtenido los parabienes de los escritores. De sus obras, sin embargo, se estuvo abasteciendo el mercado editorial desde la aparición de $E I$ sobremesa y alivio de caminantes, de la que se conocen dos ediciones con este título, la primera en Zaragoza, $1563^{20}$, y en Valencia, 1569, la segunda. Una versión más aligerada, y que contenía un título también abreviado, Alivio de caminantes, apareció en Medina del Campo, 1563, y fue reeditada en Alcalá de Henares, 1576; Amberes, 1577; Évora, 1575; Sevilla, 1596, y en esta misma ciudad en 1603. De El buen aviso y portacuentos, que vio la luz en Valencia, en 1564, no se conocen otros testimonios antiguos. En cambio, del Patrañuelo tenemos varias ediciones; apareció originalmente en Valencia, 1567, y después se reeditó en Alcalá de Henares, 1576; Barcelona, 1578; Bilbao, 1580; y Sevilla, 1583.

La pertinencia de esta relación de ediciones se manifiesta sintomáticamente cuando atendemos al considerable número de impresiones que encontramos hasta el texto sevillano del Patrañuelo publicado 1583 (con excepción de las aparecidas en la misma ciudad en 1596 y 1603 del Alivio de caminantes). La aparición en 1580 en la ciudad de Bilbao, a costa de Juan Ruelle (el mismo editor que patrocina el Patrañuelo en ese año y también en esa ciudad), de la versión de Straparola al castellano supone un frenazo en brusco del éxito comercial de las recopilaciones de Timoneda, que durante las décadas de los sesenta y setenta no habían encontrado competencia en el mercado editorial. De las ediciones de estas obras del librero valenciano hasta llegar a Mateo Alemán (cuyo Guzmán de Alfarache se editó en 1599, aunque obtuvo el privilegio a principios del año anterior, y experimentó un éxito inmediato) y a Cervantes (1605) hay, en la historia de la novela corta en España, un salto en el tiempo que no se entiende si no se considera la serie de colecciones del italiano que se tradujeron en la época de los ochenta del siglo XVI y se pone en relación con la producción literaria anterior y posterior. Desde que apareció en el mercado la obra de Straparola vertida al castellano, un total de catorce ediciones conocieron las 
traducciones de los novelistas italianos en España en poco más de treinta años:

1580: Straparola, Honesto y agradable entretenimiento, Matías Mares, a costa de Juan Ruelle, Bilbao.

1581 (Colofón: 1582): Straparola, Segunda parte del honesto y agradable entretenimiento, Juan Baptista de Montoya, a costa de Antonio de Vega, Baeza.

1582: Straparola, Segunda parte del honesto y agradable entretenimiento, Juan Baptista de Montoya, a costa de Antonio de Vega, Baeza.

1582 (Colofón: 1583): Straparola, Honesto y agradable entretenimiento, René Rabut, a costa de Francisco García y Juan Díaz, Granada.

1583: Straparola, Segunda parte del honesto y agradable entretenimiento, Juan Baptista de Montoya, a costa de Antonio de Vega, Baeza.

1586: Guicciardini, Horas de recreación, Matías Mares, a costa de Juan de Millis, Bilbao.

1588: Guicciardini, Primera parte de los ratos de recreación, Pedro Puigi y Juan Escarrilla, Zaragoza.

1589: Bandello, Historias trágicas ejemplares, Pedro Lasso, a costa de Juan de Millis, Salamanca.

1590: Giraldi Cinzio, Primera parte de las cien novelas, Pedro Rodríguez, a costa de Julián Martínez, Toledo.

1596: Bandello, Historias trágicas ejemplares, Pedro Madrigal, a costa de Claudio Curlet, Madrid.

1598: Straparola, Primera y segunda parte del honesto y agradable entretenimiento, Luis Sánchez, a costa de Miguel Martínez, Madrid.

1603: Bandello, Historias trágicas ejemplares, Lorenzo de Ayala, a costa de Miguel Martínez, Valladolid.

1612 (Colofón: 1611): Straparola, Primera parte del honesto entretenimiento de damas y galanes, Nicolás de Asiaín, a su costa, Pamplona.
1612: Straparola, Segunda parte del honesto y agradable entretenimiento de damas y galanes, Nicolás de Asiain, a su costa, Pamplona.

Esta relación pone de manifiesto el éxito editorial que se produce entre 1580 y 1590 (década que arroja unos resultados espectaculares: cuatro autores traducidos, cinco textos originales y nueve impresiones) frente al notable descenso que conocen los novellieri a partir de la fecha en la que aparece la Primera parte de las cien novelas de Giraldi Cinzio (en más de veinte años no se traducen nuevas obras, y sólo encontramos cinco ediciones de dos autores, Straparola y Bandello). Es obvio que el importante número de obras traducidas en la década de los ochenta contrasta poderosamente con la intermitencia con la que se reeditan a partir de 1590 Straparola et alii. Si a estos datos le unimos que tenemos constancia de varias obras más que fueron traducidas (una segunda parte de la colección de Bandello, las novelas de Sansovino) en los ochenta y que nunca vieron la luz, posiblemente encontremos la razón que explique la ausencia de traducciones a partir de 1590.

Fácilmente se pudo extender, entre mercaderes de libros e impresores, la noticia de que a ciertas traducciones de algunos novellieri no se les estaban concediendo las aprobaciones correspondientes para poder imprimirse legalmente; en ese momento era más viable apostar por aquellos que habian sido ya "aprobados" por la Iglesia que tratar de obtener las debidas licencias para nuevas traducciones. Era evidente, por el interés que mostró Juan de Millis, por ejemplo, que los libreros no habían perdido su voluntad de continuar costeando este tipo de libros. Pero es de sobra conocido que los últimos años del reinado de Felipe II fueron económicamente infaustos, lo que pudo generar un empobrecimiento del mercado editorial, y ya a la llegada del nuevo siglo, al que le da la bienvenida el Guzmán de Alfarache, la narrativa experimenta interesantes novedades, con el remozamiento de algunos géneros y el rescate editorial de otros (Moll, 2008). Estas circunstancias fueron principalmente las que provocaron la disolución de un prototipo de obras que se había introducido en España a través del Decamerone y que en la década de los setenta, cuando comienzan a ser traducidos, revolucionó el panorama de la novela en España hasta propiciar un nuevo género que gozaría de una enorme popularidad durante el siglo XVII. 


\section{Marco para una ReVISIÓN históRICO-CRítica: LÍNEAS METODOLÓGICAS DE UN PROYECTO EN CIERNES}

Ante la acuciante necesidad de estudiar esta etapa de la novela en España, me permitiré en los párrafos que siguen plantear una serie de cuestiones que han de ser indiscutiblemente atendidas y tratadas en trabajos posteriores, a los que este ensayo preliminar sirve de demarcación y horizonte. Con esta metodología sistemáticamente planeada se pretende ofrecer, en líneas maestras, las ricas y variadas posibilidades -de las que se pueden derivar, además de las aquí registradas, otras tantas- que brinda este fecundo campo de investigación, que ha permanecido prácticamente sin roturar desde los inicios de la crítica moderna.

I) Es preciso realizar una catalogación y descripción de todas las ediciones que tuvieron estas traducciones casteIlanas. El manejo del máximo número de ejemplares puede brindarnos hallazgos inopinados, como por ejemplo la segunda emisión descubierta ahora de la obra de Guicciardini con el documento de la tasa impreso, lo que nos debe llevar a explicar y razonar las contingencias editoriales que pudo conllevar. Quizá un rastreo sistemático de los ejemplares localizados pueda depararnos cierto descubrimiento que aporte alguna solución al interrogante que se ha planteado, por ejemplo, con respecto a la ampliación de Truchado de la licencia de impresión para las dos partes del Honesto y agradable entretenimiento; 0 , en otro caso, que plantee la posibilidad de alguna edición perdida, como aquellas de Bandello o Sansovino para las que se pidieron licencias de impresión. Aunque parece que el número de ediciones está cerrado, la bibliografía es siempre un campo potencialmente abierto, y la búsqueda ordenada de títulos podría sorprendernos con el descubrimiento de algún ejemplar nunca antes registrado; en este sentido, la exploración de catálogos antiguos podría ofrecernos noticias referidas a posibles testimonios que no han llegado hasta nosotros, por lo que en este caso, al menos, sería necesario fundamentar si se trata o no de una edición fantasma.

II) Desde la sociología de la edición también se debe plantear un amplio estudio que atienda a las alianzas entre traductores, editores e impresores. Es notablemente interesante la relación de los hermanos Millis con el estallido de la novella: tuvieron la suficiente perspicacia, en un momento de interés creciente por este género de libros, de hacerse con la traducción de varios autores (Guicciardini, Bandello, Sansovino) de éxito en Italia. Los vínculos establecidos entre los talleres que imprimen la traducción de Truchado en Baeza y Granada, así como la relación de Truchado con los nuevos dedicatarios, de quien intentaría conseguir favores, es otro terreno de indudable interés. Si pudiésemos acceder a los contratos de compra-venta de los traductores con los editores, tendríamos en nuestras manos un minero de datos de incalculable valor para estimar en qué términos se produjo el concierto entre las partes.

Sin embargo, muchas de estas líneas apuntan en una dirección evidente que trata de aclarar de quién partió la idea de introducir a los novellieri en España. Menéndez Pelayo y Amezúa se fijaron exclusivamente en los editores y libreros, pensando que fue desde este gremio desde donde se propició un mayor interés por sembrar en España lo que en Italia había dado tantos frutos; desde luego, con el ejemplo de la familia Millis esta teoría cobra sentido, pero ¿ocurre lo mismo con el resto de los casos? A Francisco Truchado le hallamos vendiendo la licencia de impresión del Honesto y agradable entretenimiento a los editores granadinos en 1576, quienes la cedieron para su explotación a Juan Ruelle, que la mandó imprimir en 1580 en Bilbao; después, según las nuevas ediciones que encontramos de la primera y la segunda parte de la obra de Straparola, algunas con nuevas dedicatorias, Truchado debió de seguir interviniendo de una u otra forma en las negociaciones con sus editores para poder obtener beneficios indirectos. En este caso, difícilmente podremos sostener que la obra de Straparola se tradujo por incentivos generados desde el gremio de los editores.

En tal sentido, el ejemplo de las traducciones de Mondragón y de Vozmediano, aunque distintos, tampoco creo que deban atribuirse al interés por parte de miembros del círculo de los libreros e impresores. El primero acometió la traducción de una obra que ya había aparecido en el mercado editorial, por lo que difícilmente la idea había podido partir de un librero con ansias de obtener beneficios ${ }^{21}$; además, la labor de Mondragón, remozando el texto original y agregando partes de diferentes autores, no se aviene con el perfil de un traductor a sueldo que tiene que realizar una tarea por encargo de forma más o menos urgente. El caso de Vozmediano ratifica en buena medida mis sospechas de que el trabajo de estos traductores no fue ni solicitado ni 
remunerado en muchas ocasiones; en su cuidado prólogo, Vozmediano, como se ha visto, se involucró de manera avivada con el nacimiento de la novela en España y marcó un punto de partida para el inicio de la nueva etapa que se abría en la década de los noventa. Por tanto, habría que revisar a fondo esa idea que tanto Menéndez Pelayo como Amezúa establecieron en sus estudios partiendo del análisis detenido de estos ejemplos.

Sería interesante, en este mismo orden, estudiar con qué otro tipo de obras trabajaron estos traductores (que al parecer tenían otros oficios y por tanto no todos eran profesionales), y si se dedicaron a esta labor de forma ocasional o no. Igualmente, podríamos observar si otros trabajos de traducción de Truchado, Mondragón o Millis guardan alguna relación literaria con las traducciones de las que estoy dando cuenta o si, por el contrario, pertenecen a géneros totalmente distintos; y en la misma medida habría que valorar las lenguas originarias de estas obras traducidas. Con todo esto tendríamos un mapa detallado de las inquietudes culturales de los traductores, sus preferencias librescas y su competencia idiomática para la traducción.

En sentido distinto, convendria también considerar qué tipo de editores apostaron por estos libros para aumentar el mercado editorial. Vicente de Millis se ocupó de la traducción de la obra de Guicciardini, Bandello y, probablemente, Sansovino. Fue su hermano Juan de Millis quien editó las dos que vieron la luz. Juan Ruelle apostó en 1580 por la traducción de Truchado de Straparola, y en ese mismo año sabemos que financió también una edición del Patrañuelo. Hace años Laspéras (1987: 38), a este respecto, fue categórico: "L'étude des dynasties des Giunti, Portonariis, Rouilé, Millis, montre à l'évidence qu'elles dominèrent le marché du livre italien et, par conséquent, de la nouvelle et de la littérature facétieuse jusque vers les années 1580". Con los casos de Millis y Ruelle tenemos dos ejemplos evidentes de editores que advirtieron a las claras que había que invertir capital en la narrativa breve, pero sería necesario, como apuntó Laspéras, indagar en el catálogo de otros editores para, entre otras cosas, observar cuáles fueron los grandes núcleos de difusión de la novella.

Continuando con los editores, sabemos que Antonio de Vega o el impresor Nicolás de Asiaín, con la traducción de Straparola, arriesgaron su dinero en varias ocasiones para editar las traducciones de estos novelistas, por lo que se barrunta que el índice de ventas debió de ser elevado; pero durante esos años, ¿por qué tipo de obras se inclinaron? En el caso del impresor navarro, Nicolás de Asiaín, sabemos que se aventuró decididamente por este género de tradición italiana, pues solo dos años después imprimió la colección de novelas de Cervantes. De la misma forma, sería de sumo interés saber con qué imprentas estuvieron trabajando estos editores, porque Antonio de Vega tenía buenas relaciones con el taller de Bautista Montoya, pero otros fueron menos fieles a sus impresores.

III) El siguiente paso que hay que realizar es un estudio traductológico que coteje minuciosamente, casi palabra a palabra, el original italiano y la traducción española. Hubo quien, como Truchado, llegó a confesar que además de acometer su labor se había permitido hermosear el honesto entretenimiento de Straparola con algunos "versos" añadidos; Mondragón, por su parte, no encubrió que había adicionado el texto original destacando las partes propias con un asterisco, aunque al parecer olvidó señalar algunas otras que no pertenecían a Guicciardini. Por consiguiente, esta práctica nos pone en la pista de plantear otro interrogante: ¿siempre que se adicionó el texto original se llegó a reconocer? En cualquier caso, no deja de ser interesante analizar con detalle, por ejemplo en la Primera parte de los ratos de recreación, cómo se integran las facecias de los "graves escritores" escogidos y a qué responde esa selección de autores. Algún otro, como Vozmediano, se vio en la necesidad de sustituir una novela de Giraldi Cinzio por otra de Sansovino; ¿qué le impidió escoger cualquier otra pieza de la Primera parte de las cien novelas? ¿A qué responde esta maniobra del traductor y qué criterios siguió para intercalar esta novela en una selección escogida del libro original de Giraldi Cinzio?

Un estudio comparativo del original y su versión traducida nos permitirá valorar hasta dónde se llegó con esa limpieza de términos inmorales o licenciosos, dónde terminó la fidelidad al texto original y, en definitiva, cómo lograron resolver los traductores las situaciones amatorias más comprometidas o las descripciones de encendido tono. M. ${ }^{2}$ del Carmen Bobes Naves (2009: 123) cree que "a pesar de los filtros sobre términos y temas, la censura de fondo no fue estricta, y en ocasiones se presenta el adulterio como un divertimento, el robo queda impune y se celebran las gracias de mancebos libidinosos". Sin embargo, los traductores sabian que estaban trabajando con una materia peli- 
grosa que podía fácilmente ser reprobada por los censores, y en algunos casos lo fue, pues la licencia eclesiástica de determinadas obras ponía de manifiesto que el libro se mandaba a imprenta expurgado.

Esto es indicativo de que quizá los traductores no llevaron a término una limpieza tan drástica como aseguraban, y tal vez también pudieron en algún caso aprovechar los prólogos, como destacó Julia Barella (1985: 22, 28 y 23 respectivamente), con el fin de aplicar "fórmulas de captar la benevolencia del lector y el favor del poder civil y eclesiástico para las aprobaciones", aunque tal práctica quizá fuese solo una táctica "para ganarse al lector" o un "truco publicitario"; el evidente "desequilibrio entre prólogo y texto" hace sospechar que probablemente los traductores no fueron tan prudentes y decorosos en su labor como prometian en los textos proemiales. Por tanto, conocidos estos documentos firmados por los censores, que muestran a las claras el doble tamiz que tuvieron las traducciones de las colecciones de novelas italianas (las enmiendas del revisor y las del propio traductor), difícilmente podremos fijar los límites de las labores del traductor y del censor cuando detectemos modificaciones de estilo $u$ otros arreglos puntuales. Este doble escrutinio nos coloca ante una serie de libros que, en calidad de traducciones, son verdaderamente ricos para que pueda ser tasado y evaluado el ejercicio de los traductores y, por extensión, el desnivel socio-cultural que existía entre Italia y España.

Parece manifiesto que la censura desempeñó un papel decisivo en la prohibición de algunas traducciones que habían obtenido licencias reales de impresión. La Inquisición yuguló un prometedor proyecto editorial planificado por los hermanos Millis y sin lugar a dudas cercenó la difusión de los novellieri en España en el momento de su apogeo, limitando el número de títulos y ediciones que aparecieron en los años ochenta. De no haber sido por esta rígida represión, que puso fecha de caducidad a la proyección de los novellieri en España, el impacto editorial hubiese sido sin duda mucho más destacable; quizá si hubiese habido más condescendencia con estas colecciones de novelas y se hubiesen autorizado aquellas obras que se quedaron en cuarentena esperando una licencia eclesiástica que nunca llegó, la reacción de los escritores españoles no se habría demorado tanto. Posiblemente, como en tantos otros aspectos, la fiscalización de estos libros por parte de la Inquisición provocó una suspensión temporal en la aparición de la novela corta española, que inició sus pasos camuflada en obras de diferente naturaleza, y cuando sus autores vieron la oportunidad de entregarlas a la imprenta formando colecciones insistían con redoblados argumentos en la ejemplaridad y honestidad de sus historias relatadas.

Todos estos acercamientos previos han de servir de estudios preparatorios para conformar el marco idóneo que desde el punto de vista histórico-crítico faculte una recuperación editorial de estas obras. Si se llegasen a abordar estas ediciones con criterios filológicos fiables, podríamos conocer con cierto detalle cómo trabajaron los impresores con las reediciones de Straparola y Bandello: ¿suprimieron, añadieron o sustituyeron según las necesidades materiales o las exigencias tipográficas determinadas partes del texto? ¿Hasta qué punto pudieron adulterar las versiones que se imprimieron en las ediciones príncipes? Para poder tener un texto editado con garantías crítico-textuales, es necesario localizar y analizar el "modelo subyacente" (es decir, la edición que manejó el traductor). Con este testimonio de la tradición italiana, que seguramente presentará variantes con respecto al original, se podrá distinguir entre las lecciones auténticas de la traducción al castellano (y que dependen de tal modelo) y las variantes textuales 0 errores de imprenta que pertenecen exclusivamente a la tradición española (y que se deben a la transmisión impresa del texto ya traducido). Es evidente que si no se escogió la primera edición, casi con toda seguridad tendremos más cambios que añadir a ese doble filtro formado por traductores y censores. De esta forma podremos hacernos una idea suficientemente aproximada de la distancia estéticoliteraria de la obra surgida de la pluma de los novellieri y la traducción que se difundió en España.

Maxime Chevalier (1989: 165) sentenció que "la historia de la novela breve empieza con la Primera parte de Guzmán y la Primera parte del Quijote: los textos compuestos con anterioridad que calificamos de novelas cortas pertenecen a la prehistoria del género". Parece evidente que en esa etapa fundacional ocupa un lugar esencial la difusión de los novellieri. No deja de ser interesante que todas estas traducciones se realicen poco después del éxito de Timoneda, ni mucho menos que casi inmediatamente después Alemán en su Guzmán de Alfarache (1599) y Cervantes (antes de publicar el Quijote, 1605, ya tenía compuestas algunas de sus novelas ejemplares, que están fechadas, según las noticias que han llegado hasta nosotros, en la 
última década del siglo XVI) empiecen a crear novelas emulando el modo italianista. Por tanto, ni es casual que a partir de la década de los noventa dejen de traducirse a los novelistas italianos (porque parece que a partir de esa fecha los españoles han entendido que hay que hacer "lo que nunca han hecho, que es componer novelas"), ni tampoco que la fecha en la que se reedita la última colección sea la de 1612, año en el que Cervantes inicia el proceso para obtener la licencia y aprobación con el propósito de sacar al mercado cuanto antes sus Novelas ejemplares, una obra que a partir de su fecha de lanzamiento (otoño de 1613) fagocita el mercado editorial, conociendo tres ediciones -una de ellas contrahecha- que no respetaron el privilegio que tenía el editor ${ }^{22}$. Las Noches de invierno de Antonio Eslava (1609) no pudieron evitar una nueva reedición de las dos partes del libro de Straparola, algo que sí consiguiera las Novelas ejemplares, dándole el cerrojazo definitivo a los novellieri, que con su llegada a España habian cumplido un papel decisivo en el origen de nuestra novela corta del Siglo de Oro.

\section{NOTAS}

1 Un esbozo de este trabajo fue presentado en la "Jornada sobre literatura española del Siglo de Oro" (Universidad de Jaén), dedicada a la Novela corta y organizada por C. Castillo Martínez. Hago aquí manifiesto mi agradecimiento a la Dra. Castillo por la oportunidad que me brindó de abordar un tema muy olvidado por la crítica española, además de aprovechar también estas líneas para mostrar mi endeudamiento con varias personas que han mejorado con sugerentes anotaciones este artículo: A. Baldissera, C. Castillo, A. Henríquez, R. Malpartida, D. Pirovano, F. de los Reyes y, muy especialmente, G. Caravaggi, J. Lara y A. Ruffinatto. Por otra parte, debo hacer ostensible que este trabajo se enmarca en las líneas de investigación de dos proyectos en los que participo, comprendidos ambos en el plan Nacional de I+D+i del Ministerio de Ciencia e Innovación: "La recepción y el canon de la literatura española del Siglo de Oro en los siglos XVIII, XIX y XX" (FFI2009-10616subprograma FILO), cuyo investigador principal es J. Lara Garrido, y "Pampinea y sus descendientes: 'novella' italiana y española frente a frente (I)"
(FFI2010-19841-subprograma FILO), cuya investigadora principal es I. Colón Calderón.

2 Poco más tarde, en 1614, se reafirmó (1991: 114) en un terceto de su Viaje del Parnaso: "Yo he abierto en mis novelas un camino/por do la lengua castellana puede/mostrar con propiedad un desatino" (IV, 25-27).

3 En las actas del Congreso Internacional "Novela corta y teatro en el Barroco español (1613-1685): vínculos y relecciones. Homenaje al prof. Anthony Close", próximas a ver la luz, aparecerá una contribución de la hispanista Giulia Giorgi en la que señala bastantes pasajes que demuestran la lectura directa que hizo Castillo de la versión original de Straparola.

4 Es preciso indicar que de los novellieri que fueron traducidos al castellano sólo Bandello ha conocido varias ediciones modernas. Véase la nota 12.

5 Romera Pintor ha dedicado más estudios y ediciones a la obra de Giraldi Cinzio, pero centrados principalmente en su faceta como dramaturgo. Antes de ver la luz estos últimos trabajos apareció un escuálido panorama de Esperanza Seco (1989) sobre la "influencia de la literatura italiana en la española", que sería complementado por otro trabajo (1990) en el que los
Aceptado: 29 de junio de 2011 
novellieri casi ocupan un lugar anecdótico.

6 La primera de estas contribuciones estará dedicada a la difusión de la obra de Straparola y al importante papel que desempeñó su traductor, Francisco Truchado, en avivar el interés por la novela corta. La bibliografía que colaciono y reúno en este primer ensayo es limitada; reservo para los diferentes estudios que complementarán a este una relación bibliográfica más exhaustiva.

7 Acompañará en otro número de Arbor y como suplemento a esta contribución un corpus textual formado por aquellos escritos de más interés (censuras, prólogos y dedicatorias) incluidos en los preliminares de las obras aqui estudiadas: "En el origen de la novela corta: los novellieri desde sus paratextos"; en la nota introductoria especifico los criterios editoriales adoptados, que rigen también para las citas que aquí traigo a colación.

8 Bonilla Cerezo (2011: 30, n. 20), quien también ha insistido recientemente en la necesidad de estudiar a los novelistas italianos (traducidos y no traducidos), ha manifestado que se está ocupando "de la versión española del libro de Straparola".

9 De esta edición se conocen dos emisiones (Cátedra, 2001: 223-227). En su monografía, Cátedra aclaró el fárrago editorial que había en torno a las ediciones baezanas; hasta ese momento la crítica mostraba serias dudas a la hora de fechar las primeras ediciones del texto; el ejemplo de Aldomà García (1998: 322) es, en este sentido, señero: "Francisco de Truchado traduce en 1580 las Piacevoli Notti de Straparola con el título de Honesto y agradable entretenimiento de damas y galanes. Resulta difícil situar cuál fue la primera edición de
Honesto y agradable entretenimiento, parece ser que hubo una primera y segunda parte en Bilbao, reimpresas en Baeza en 1581 y luego en Granada en 1582 con algunas modificaciones. De las varias ediciones en pocos años se colige que la obra gozó de un notable éxito".

10 Cf. A. Rojo Vega (1994: 134).

11 De esta primera y única edición existen dos estados de edición; una contiene el vuelto de la portada en blanco, mientras que la otra conserva impreso el documento de la tasa, firmada por Lucas Camargo, en la que se dice que cada volumen se ha de vender a tres maravedis el pliego (cantidad que está manualmente añadida con un tipo de imprenta en el pie de portada: "Está tasado en.3. maravedis").

12 Esta traducción de Bandello puede ser consultada, a través de su digitalización, en la Biblioteca Digital de la Universitat de València. El texto de Bandello ha sido el que más veces ha conocido traducciones parciales a nuestra lengua; en el siglo XIX José Feliú y Codina (1884) realizó una nueva traducción con el título de Novelas escogidas. A esta le sigue las Novelas seleccionadas (s.a.) con prólogo de Agustín del Saz, editadas en CIAP. La última que ha visto la luz (1943) ha sido la publicada por Ediciones Atlas, que sigue la tercera edición antigua de la obra (Valladolid, Lorenzo de Ayala, 1603), aunque solo contiene las novelas primera, segunda, sexta, duodécima, decimotercera y decimocuarta.

13 La obra de Francesco Sansovino a la que se hace referencia apareció originalmente en Venecia, 1561, con el título Cento novelle scelte da più nobili scrittori della lingua volgare. Más abajo se verá cómo a la colec- ción de Sansovino acudió Gaitán de Vozmediano, el traductor de Giraldi Cinzio, para sustituir una novela de este autor.

14 En su trabajo, Rojo Vega (1994: 130, n. 4) admitía que no había inspeccionado "los Libros de Cédula, ni los Memoriales de Cámara, donde previsiblemente puede haber documentación relativa al tema, como en tantas otras secciones del complejo Archivo de Simancas".

15 Se trata de una rarisima edición, no descrita, según mis consultas, en los catálogos de C. Pérez Pastor (1891-1907), ni Y. Clemente San Román (1998), ni tampoco en el de traducciones del Proyecto Boscán (http://www.ub.edu/boscan) [20/06/2011]. Hasta el momento sólo he hallado un único ejemplar de esta edición madrileña, depositado en la Universidad de Oviedo (CGR-553).

16 La naturaleza de esta traducción del francés, en la que intervinieron los dos traductores de Bandello a esa lengua, puede ser perfectamente ligada a las colecciones que se imprimieron de los novelistas italianos. La obra se publica en Medina del Campo, en el taller de Francisco del Canto, a costa de Benito Boyer, en 1586, y se reeditó en 1603 en Madrid, en la imprenta de Luis Sánchez, a costa de Bautista López. Menéndez Pelayo (1943 [1910]: 41) sospechaba que era "muy verosímil que las Historias prodigiosas se imprimiesen por primera vez en Sevilla, donde tenía su establecimiento tipográfico Andrea Pescioni. Pero no encuentro noticia alguna de esta edición, y sólo he manejado las dos siguientes". Sin embargo, todavía hoy esta conjetura del autor de los Orígenes de la novela no ha podido confirmarse. A esta obra le dedicó Menéndez Pelayo numerosas páginas, pero sin duda las 
notas que dejó sobre la traducción (1943 [1910]: 42-43, n. 1) animan a que se realice un estudio a fondo del asunto: "Al fin añadió el traductor tres historias de su cosecha [...]. Además intercala en el texto alguno que otro párrafo suyo, por ejemplo éste (fol. 54 de la edición de Madrid), al tratar de ciertos peces voladores [...]. Ocasionalmente traduce algunos versos de Virgilio, Horacio y Lucano, y también algunos de Ronsard (pp. 254, 255, 384, 395), de Boyssiero (p. 388) y de otro poeta francés (en lengua latina) cuyo nombre no expresa (p. 292). Estas versiones no son inelegantes".

17 Me refiero naturalmente a la labor de Joan Timoneda, que preparó varias colecciones fuertemente influenciadas por las impresas en Italia: Sobremesa y alivio de caminantes (1563), El buen aviso y portacuentos (1564) y el Patrañuelo (1567). Los títulos que listo a continuación deben entenderse a modo de contextualización epocal, por lo que no entro en calcular la pervivencia de estos géneros en el siglo XVI ni en su cruce con el XVII.

18 La obra de Boccaccio había conocido un considerable éxito en poco más de medio siglo (Fernández Murga, 1986); sin enumerar testimonios manuscritos, desde la princeps, aparecida en Sevilla (1496), la obra de Boccaccio se imprimió cuatro veces más: Toledo (1524), Valladolid (1539), Medina del Campo (1543) y Valladolid (1550). Su proyección en la literatura española desde el medievo ha sido sucintamente reescrita por A. Ruffinatto (2006) en un fundamentador ensayo.

19 Fue Maxime Chevalier (1989: 164) quien acuñó el concepto "cuento novelado" para marcar el "género fronterizo" entre el cuento y la novela corta.

20 Hay ciertos indicios que apuntan a que esta edición parte de otra perdida de Valencia, publicada en el mismo año (Judith Farré Vidal/EdoBNE, 2010: 921-923).

21 En ese hipotético caso, cualquier editor de otro reino en el que el privilegio no tuviese vigencia habría mandado imprimir el texto a plana y renglón, siguiendo la misma traducción, y así se hubiese ahorrado los honorarios del traductor y parte de la suma del taller de imprenta, en el que no hubiese sido necesario gastar tiempo en hacer la cuenta del original.

22 Una de estas tres ediciones de 1614, como antes anoté, fue costeada por Nicolás de Asiaín, quien habia apostado decididamente por este género, que en España empezaba a reverdecer después del éxito de los novellieri en la década de los ochenta.

\section{BIBLIOGRAFÍA}

Aldomà Garcia, Mireia (1996): "Los Hecatommithi de Giraldi Cinzio en España", en Studia Aurea: actas del III Congreso de la AISO, III, I. Arellano, C. Pinillos, M. Vitse y F. Serralta (coords.), Griso/ Lemso, Navarra/Toulouse, pp. 15-22.

- (1998): La recepción de la novella en España: los Hecatommithi de Giraldi Cinzio, Bellaterra, Publicacions de la Universitat Autònoma de Barcelona [Microforma].

Arredondo, Maria Soledad (1989): "Notas sobre la traducción en el Siglo de Oro: Bandello Francoespañol", en Imágenes de Francia en las letras hispánicas, F. Lafarga (ed.), PPU, Barcelona, pp. 217-227.
Bandello, Mateo (1589), Historias trágicas ejemplares, Pedro Lasso, a costa de Juan de Millis, Salamanca.

- (1596): Historias trágicas ejemplares, Pedro Madrigal, a costa de Claudio Curlet, Madrid.

- (1603): Historias trágicas ejemplares, Lorenzo de Ayala, a costa de Miguel Martínez, Valladolid.

- (1884): Novelas escogidas, traducción de J. Feliú y Codina, Daniel Cortezo y C. ${ }^{a}$, Barcelona.

- (s.a.): Novelas seleccionadas, prólogo de A. del Saz, CIAP, Madrid.

- (1943): Historias trágicas, nota preliminar de M. Menéndez Pelayo, Ediciones Atlas, Madrid.

Barella, Julia (1985): "Las novelle y la tradición prosística española", Estudios Humanísticos. Filología, 7, pp. 21-29.

Boaistuau, P.; Tesserant, C.; y Belleforest, F. (1586): Historias prodigiosas y ejemplares, Medina del Campo, Francisco del Canto, a costa de Benito Boyer.

- (1603): Historias prodigiosas y ejemplares, Madrid, Luis Sánchez, a costa de Bautista López.

Bobes Naves, Maria del Carmen (2009): "Modalizaciones en las novelas cortas cervantinas", Dialogía, 4, pp. 118-141.

Bonilla Cerezo, Rafael (2011): "'Proemio' e 'Introducción a las novelas' del Teatro popular de Francisco Lugo y Dávila: estudio y edición", Edad de Oro, XXX pp. 25-68.

Bourland, Caroline B. (1905): "Boccaccio and the Decameron in the castilian and catalan literature", Revue Hispanique, XII, pp. 1-232.

- $\quad$ (1927): The short story in Spain in the Seventeenth Century, with a bibliography of the novela from 1576 to 1700, Smith College, Northanmpton [Edición facsímil: Burt Franklin, Nueva York, 1973).

Castillo Solórzano, Alonso del (1992): Tardes entretenidas [1625], edición 
de P. Campa, Montesinos, BarceIona.

Cátedra, Pedro M. (2001), Imprenta y lectura en la Baeza del siglo XVI, Seminario de Estudios Medievales y Renacentistas, Salamanca.

Cayuela, Anne (1993): "La prosa de ficción entre 1625 y 1634 . Balance de diez años sin licencias para imprimir novelas en los reinos de Castilla", Mélanges de la Casa de Velázquez, XXIX, 2, pp. 51-76.

- (2011): "Libros de entretenimiento en la librería de Ana de Arenas: consecuencias editoriales y literarias de la suspensión de licencias para novelas y comedias (1625-1634)", en Poder y saber. Bibliotecas y bibliofilia en la época del conde-duque de Olivares, 0. Noble Wood, J. Roe y J. Lawrance (eds.), CEEH, Madrid, pp. 262-284.

Cervantes, Miguel de (1991): Viaje al Parnaso [1614], edición de E. L. Rivers, Espasa Calpe, Madrid.

- (2001): Novelas ejemplares [1613], edición de J. García López, estudio preliminar de J. Blasco, Crítica, Barcelona.

Clemente San Román, Yolanda (1998): Tipobibliografía madrileña. La imprenta en Madrid en el siglo XVI (15661600), I-III, Edition Reichenberger, Kassel.

Chevalier, Maxime (1989): "La emergencia de la novela breve", en Homenaje al profesor Antonio Vilanova, I, M. C. Carbonell y A. Sotelo Vázquez (coords.), PPU, Barcelona, pp. 157-168.

Farré Vidal, Judith/EdoBNE (2010): "Juan de Timoneda (¿Valencia?, ¿?-Valencia, 1583)", en Diccionario Filológico de Literatura Española, Castalia, Madrid, pp. 920-927.

Fernández Murga, Félix (1986): "Las primeras traducciones españolas de la obra de Boccaccio", en Studi di iberistica in memoria de Giuseppe Carlo Rossi, Napoli, pp. 68-177.
Giraldi Cinzio, Giambattista (1590): Primera parte de las cien novelas, Pedro Rodríguez, a costa de Julián Martínez, Toledo.

González de Amezúa, Agustín (1951): Formación y elementos de la novela cortesana [1929], en Opúsculos histórico-literarios, I, CSIC/Instituto Miguel de Cervantes, Madrid.

- (1982): Cervantes, creador de la novela corta española [1956] I, CSIC/ Instituto Miguel de Cervantes, Madrid.

Guicciardini, Ludovico (1586): Horas de recreación, Matías Mares, a costa de Juan de Millis, Bilbao.

- (1588): Primera parte de los ratos de recreación, Pedro Puigi y Juan Escarrilla, Zaragoza.

Laspéras, Jean-Michel (1987): La nouvelle en Espagne au Siècle d'Or, Universitè de Montpellier.

Menéndez Pelayo, Marcelino (1943): Orígenes de la novela [1910], III, CSIC, Madrid.

Moll, Jaime (1974): "Diez años sin licencias para imprimir comedias y novelas en los reinos de Castilla: 1625-1634", Boletín de la Real Academia Española, LIV, CCl, pp. 97-103.

- (2008): "La narrativa castellana a comienzos del siglo XVII: aspectos editoriales", Anales Cervantinos, XL, pp. 31-46.

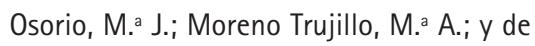
la Obra Sierra, J. M. a (2001): Trastiendas de la cultura. Librerías y libreros en la Granada del siglo XVI, Universidad de Granada.

Pérez de Montalbán, Juan (1992): Sucesos y prodigios de amor, edición de L. Giuliani, Montesinos, Barcelona.

Pérez Pastor, Cristóbal (1891-1907): Bibliografía madrileña o descripción de las obras impresas en Madrid, I-III, Tipografía de los huérfanos, Madrid.
Prieto, Antonio (1986): La prosa española del siglo XVI, I, Cátedra, Madrid.

Proyecto Boscán (en línea): Catálogo de las traducciones españolas de obras italianas (hasta 1939) http://www. ub.edu/boscan [20/06/2011].

Rojo Vega, Anastasio (1994): "Manuscritos y problemas de edición en el siglo XVI", Castilla, 19, pp. 129-157.

Romera Pintor, Irene (1998): Giraldi Cinzio: Metodología y Bibliografía, AEMCC, Madrid.

Ruffinatto, Aldo (2006): "Il Decameron nella letteratura spagnola (Dal Conde Lucarnor alle Edades de Lulú)", en II Decameron nella letteratura europea, C. Allasia (ed.), Edizioni di storia e letteratura, Roma, pp. 183204.

Seco, Esperanza (1989): "Influencia de la literatura italiana en la española", Didáctica (Lengua y Literatura), 1, 1989, pp. 121-132.

(1990): "Historia de las traducciones literarias del italiano al español durante el Siglo de Oro (influencias)", Cuadernos para investigación de la literatura hispánica, 13, pp. 41-98.

Straparola, Giovanni Francesco (1580): Honesto y agradable entretenimiento, Matías Mares, a costa de Juan Ruelle, Bilbao.

- (1581): Segunda parte del honesto y agradable entretenimiento [Colofón: 1582], Juan Baptista de Montoya, a costa de Antonio de Vega, Baeza.

- (1582): Segunda parte del honesto y agradable entretenimiento, Juan Baptista de Montoya, a costa de Antonio de Vega, Baeza.

- (1582): Honesto y agradable entretenimiento [Colofón: 1583], René Rabut, a costa de Francisco García y Juan Díaz, Granada.

- (1583): Segunda parte del honesto y agradable entretenimiento, Juan Bap- 
tista de Montoya, a costa de Antonio de Vega, Baeza.

- (1598): Primera y segunda parte del honesto y agradable entretenimiento, Luis Sánchez, a costa de Miguel Martínez, Madrid.
- (1612): Primera parte del honesto entretenimiento de damas y galanes [Colofón: 1611], Nicolás de Asiaín, a su costa, Pamplona.

- (1612): Segunda parte del honesto y agradable entretenimiento de damas y galanes, Nicolás de Asiaín, a su costa, Pamplona.

Vega, Lope de (2007): Novelas a Marcia Leonarda [1621 y 1624], edición de M. Presotto, Castalia, Madrid. 